Columbia Law School

Scholarship Archive

1988

\title{
The Scope of Consular Immunity under the Vienna Convention on Consular Relations: Towards a Principled Interpretation
}

Curtis J. Milhaupt

Follow this and additional works at: https://scholarship.law.columbia.edu/faculty_scholarship

Part of the Comparative and Foreign Law Commons, and the International Law Commons

\section{Recommended Citation}

Curtis J. Milhaupt, The Scope of Consular Immunity under the Vienna Convention on Consular Relations: Towards a Principled Interpretation, 88 CoLUM. L. REV. 841 (1988).

Available at: https://scholarship.law.columbia.edu/faculty_scholarship/149

This Article is brought to you for free and open access by the Faculty Publications at Scholarship Archive. It has been accepted for inclusion in Faculty Scholarship by an authorized administrator of Scholarship Archive. For more information, please contact scholarshiparchive@law.columbia.edu. 


\section{THE SCOPE OF CONSULAR IMMUNITY UNDER THE VIENNA CONVENTION ON CONSULAR RELATIONS: TOWARDS A PRINCIPLED INTERPRETATION}

\section{INTRODUCTION}

A consular officer, mistaken for a trespasser as he leaves his mission to attend a cultural function, struggles with a police officer and is subsequently charged with assault and battery. ${ }^{1}$ The Vienna Convention on Consular Relations ${ }^{2}$ provides that consular officers ${ }^{3}$ are immune from jurisdiction for "acts performed in the exercise of consular functions." 4 Does the Vienna Convention shield the consular officer from suit? The scope of consular immunity is uncertain because courts differ in their application of the Convention's immunity rule.

This Note argues that a principled interpretation of the scope of consular immunity consistent with the Vienna Convention requires a functional approach, ${ }^{5}$ based on whether immunity for the act giving rise to suit is necessary for the performance of a recognized consular function. Part I describes the Vienna Convention's treatment of consular immunity and examines the disparate standards courts and commentators have applied in interpreting the scope of this immunity. Part II argues that functional necessity is the legal basis of consular immunity under the Convention and that the scope of the immunity is defined by balancing the interests of sending and receiving states. Part II further contends that previous standards are inconsistent with this basis. Finally, Part III defines and applies a functional test of immunity derived from the Vienna Convention, illustrating its consonance with both the theory and policy of the Convention.

1. These facts are drawn from Commonwealth v. Jerez, 390 Mass. 456,457 N.E.2d 1105 (1983).

2. Apr. 24, 1963, 21 U.S.T. 77, T.1.A.S. No. 6820,596 U.N.T.S. 261 [hereinafter Vienna Convention]. The United Nations Conference on Consular Relations adopted the Vienna Convention on April 24, 1963, along with two optional protocols. At the end of 1987, 116 states, including the United States, had ratified the Convention. Multilateral Treaties Deposited with the Secretary-General, Status as of December 31, 1987, at 72-73, U.N. Doc. ST/LEG/SER.E/6, U.N. Sales No. E.88.V.3 (1988).

3. The Vienna Convention defines "consular officer" as "any person, including the head of a consular post, entrusted in that capacity with the exercise of consular functions." Vienna Convention, supra note 2, art. 1(d).

4. Id. art. 43 , ๆ 1.

5. This Note's use of the term "functional approach" should be distinguished from that of Luke Lee, who employed it to describe the rule of customary international law that consular officers are immune for acts performed in pursuance of their official functions. See L. Lee, Consular Law and Practice 246-47 (1961). 


\section{Defining the Scope of Consular Immunity}

The Vienna Convention codified and progressively developed customary international law ${ }^{6}$ on consular immunities. ${ }^{7}$ As a party to the Convention, the United States is bound by its terms, and its provisions are part of United States law. While the Vienna Convention grants consular officers immunity from the civil, criminal, and administrative jurisdiction of the receiving state for "acts performed in the exercise of consular functions," 8 this rule, by itself, has failed to provide courts with sufficient guidance on the scope of the immunity granted and has resulted in various interpretations.

\section{A. The Vienna Convention on Consular Relations}

In the pre-Convention era, the principle that consular officers were immune only for their official acts-acts performed in the exercise of consular functions ${ }^{9}$ - was so widely followed in bilateral conventions ${ }^{10}$ and so widely accepted by both courts ${ }^{11}$ and commentators ${ }^{12}$ that it was recognized as a rule of customary international law. ${ }^{13}$ The Vienna Convention on Consular Relations, a product of the efforts of the International Law Commission ("ILC") and the Vienna Conference on

6. "Customary international law results from a general and consistent practice of states followed by them from a sense of legal obligation." Restatement (Revised) of Foreign Relations Law of the United States § 102(2) (Tent. Final Draft 1985) [hereinafter Restatement (Revised)].

7. See J. Zourek, Consular Intercourse and Immunities 34, U.N. Doc. A/CN.4/108 (1957), reprinted in [1957] 2 Y.B. Int'l L. Comm'n 71, 82, U.N. Doc. A/CN.4/SER.A/1957/Add.1.

8. Vienna Convention, supra note 2 , art. $43, \uparrow 1$.

9. The terms "official acts" and "acts performed in the exercise of consular functions" have been used interchangeably by courts and commentators, see Y. Dinstein, Consular Immunity From Judicial Process 25 (1966), and the International Law Commission, see Report of the International Law Commission to the General Assembly, [hereinafter Report of the ILC], 16 U.N. GAOR Supp. (No. 9) at 29, art. 43, comment 2, U.N. Doc. A/4843 (1961), reprinted in [1961] 2 Y.B. Int'l L. Comm'n 88, 117, U.N. Doc. A/CN.4/SER.A/1961/Add.1. However, the latter term is more precise because not all official acts, for example those specific to diplomatic functions, can be performed by consular officers.

10. For a list of such conventions, see J. Zourek, supra note 7 , at 82 , reprinted in [1957] 2 Y.B. Int'l L. Comm'n, supra note 7, at 99.

I1. See, e.g., Lyders v. Lund, 32 F.2d 308, 309 (N.D. Cal. 1929) (consular officers are immune from suits "based upon official, authorized acts, performed within the scope of their duties on behalf of the foreign state"); Arcaya v. Paez, 145 F. Supp. 464, 470-71 (S.D.N.Y. 1956) (acts of consular officer in publicizing unfavorable articles about exiled national of sending state not within scope of official duties, thus no immunity from libel suit), aff'd, 244 F.2d 958 (2d Cir. 1957).

12. See, e.g., L. Oppenheim, I International Law $\S 435$ (1955); see also Beckett, Consular Immunities, 21 Brit. Y.B. Int'I L. 34, 47 (1941) (citing authorities).

13. Report of the ILC, supra note 9 , at 29 , art. 43 , comment 2 , reprinted in [1961] 2 Y.B. Int'l L. Comm'n, supra note 9, at 117. 
Consular Relations, ${ }^{14}$ codified international law on consular immunities by providing:

Consular officers and consular employees shall not be amenable to the jurisdiction of the judicial or administrative authorities of the receiving State in respect of acts performed in the exercise of consular functions. ${ }^{15}$

In codifying the "consular functions" principle, the Vienna Convention maintained the basic difference between consular and diplomatic 16 immunities: "consular personnel enjoy immunity from legal process only in respect of official acts, whereas diplomatic agents have full personal inviolability and immunity from legal process."17

The more limited scope of consular immunity is reflected in the structure of the Vienna Convention and illustrated by comparison with the Diplomatic Convention. While both conventions provide that "it is the duty of all persons enjoying ... privileges and immunities to respect the laws and regulations of the receiving State," and "not to interfere in the internal affairs of that State,"18 laws and regulations cannot be judicially enforced against diplomatic agents because they enjoy complete criminal immunity, and complete civil and administrative immunity except insofar as they engage in a limited number of activities. ${ }^{19}$ In contrast, the duty of consular officers to respect receivingstate laws is judicially enforceable in all cases, except where article 43

14. For an account of developments leading to the signing of the Vienna Convention, see Nascimento e Silva, The Vienna Conference on Consular Relations, 13 Int'l \& Comp. L.Q. 1214, 1214-20 (1964).

15. Vienna Convention, supra note 2 , art. 43 , If 1 . The Convention allows other international agreements to provide for greater immunity. Id. art. 73, I 2. Most notable among such agreements is the Consular Convention, June 1, 1964, United States-Union of Soviet Socialist Republics, I9 U.S.T. 5018, T.I.A.S. No. 6503, which provides for complete immunity from the criminal jurisdiction of the receiving state. Id. art. 19, I 2.

I6. Diplomatic immunities are codified in the Vienna Convention on Diplomatic Relations, Apr. 16, 1961, 23 U.S.T. 3227, T.I.A.S. No. 7502, 500 U.N.T.S. 95 [hereinafter Diplomatic Convention].

17. Restatement (Revised), supra note $6, \S 463$ Reporters' Note I; see also id. at comment a (providing further comparison).

18. Vienna Convention, supra note 2, art. 55, I 1; Diplomatic Convention, supra note I6, art. 41 , I 1 . In each case, the full text is:

Without prejudice to their privileges and immunities, it is the duty of all persons enjoying such privileges and immunities to respect the laws and regulations of the receiving State. They also have a duty not to interfere in the internal affairs of that State.

Id.

19. Diplomatic Convention, supra note 16, art. 31, I 1. Diplomatic agents are not immune from civil and administrative jurisdiction in:

(a) a real action relating to private immovable property situated in the territory of the receiving State ... ; (b) an action relating to succession in which the diplomatic agent is involved ... as a private person ...; (c) an action relating to any professional or commercial activity exercised by the diplomatic agent in the receiving State outside his official functions.

Id. 
grants immunity for acts performed in the exercise of consular functions.

Because consular immunity attaches only to official acts, an important issue for the drafters of the Vienna Convention was how, and indeed whether, to codify consular functions. ${ }^{20}$ Eventually, the drafters recognized that if immunity depended upon whether an act was performed in the exercise of consular functions, it was vital that courts be able to determine the functions to which immunity would apply. ${ }^{21}$ Article 5, a nonexhaustive list of the most important consular functions, ${ }^{22}$ emerged after lengthy debate among both members of the

20. See L. Lee, Vienna Convention on Consular Relations 51 (1966). The primary source of dispute was whether to adopt a general or enumerative definition of consular functions. See id. at 52-53 (outlining principal arguments).

21. See United Nations Conference on Consular Relations, I Official Records 126, U.N. Doc. A/CONF.25/16, U.N. Sales No. 63.X.2 (1963) [hereinafter Official Records] (statement of Mr. Kirchschlaeger (Austria)) (arguing that it is "of the greatest importance" that "courts of the receiving State . . . be able to ascertain ... from an international convention" the consular functions to which immunity applies).

22. Article 5 provides

Consular functions consist in:

(a) protecting in the receiving State the interests of the sending State and of its nationals, both individuals and bodies corporate, within the limits permitted by international law;

(b) furthering the development of commercial, economic, cultural and scientific relations between the sending State and the receiving State and otherwise promoting friendly relations between them in accordance with the provisions of the present Convention;

(c) ascertaining by all lawful means conditions and developments in the commercial, economic, cultural and scientific life of the receiving State, reporting thereon to the Government of the sending State and giving information to persons interested;

(d) issuing passports and travel documents to nationals of the sending State, and visas or appropriate documents to persons wishing to travel to the sending State;

(e) helping and assisting nationals, both individuals and bodies corporate, of the sending State;

(f) acting as notary and civil registrar and in capacities of a similar kind, and performing certain functions of an administrative nature, provided that there is nothing contrary thereto in the laws and regulations of the receiving State; (g) safeguarding the interests of nationals, both individuals and bodies corporate, of the sending State in cases of succession mortis causa in the territory of the receiving State, in accordance with the laws and regulations of the receiving State;

(h) safeguarding, within the limits imposed by the laws and regulations of the receiving State, the interests of minors and other persons lacking full capacity who are nationals of the sending State, particularly where any guardianship or trusteeship is required with respect to such persons;

(i) subject to the practices and procedures obtaining in the receiving State, representing or arranging appropriate representation for nationals of the sending State before the tribunals and other authorities of the receiving State, for the purpose of obtaining, in accordance with the laws and regulations of the receiving State, provisional measures for the preservation of the rights and in- 
$\mathrm{ILC}^{23}$ and conferees to the Vienna Conference ${ }^{24}$ as a compromise between a general definition and a specific enumeration. ${ }^{25}$ Problems of interpretation generally arise as to what acts are "performed in the exercise" of the functions listed.

\section{B. Standards of Interpretation}

While the immunity rule of the Vienna Convention mandates a distinction between consular and diplomatic immunities, it does not, without more, unambiguously delimit the scope of consular immunity. Conflicting interpretations, by both courts and commentators, create uncertainty for both consular officers and the receiving-state nationals who deal with them.

1. Broad Interpretations. - Since the signing of the Vienna Convention, some courts have interpreted consular immunity broadly in both civil ${ }^{26}$ and criminal ${ }^{27}$ contexts. These courts have given generous readings to both of the provisions of the Vienna Convention that must be invoked to establish immunity: the list of consular functions in article 5 and the immunity rule of article 43 .

One court has read article $5(\mathrm{~m})$, the catch-all definition of consular

terests of these nationals, where, because of absence or any other reason, such nationals are unable at the proper time to assume the defence of their rights and interests;

(j) transmitting judicial and extra-judicial documents or executing letters rogatory or commissions to take evidence for the courts of the sending State in accordance with international agreements in force or, in the absence of such international agreements, in any other manner compatible with the laws and regulations of the receiving State;

(k) exercising rights of supervision and inspection provided for in the laws and regulations of the sending State in respect of vessels having the nationality of the sending State, and of aircraft registered in that State, and in respect of their crews;

(l) extending assistance to vessels and aircraft mentioned in subparagraph (k) of this Article and to their crews, taking statements regarding the voyage of a vessel, examining and stamping the ship's papers, and, without prejudice to the powers of the authorities of the receiving State, conducting investigations into any incidents which occurred during the voyage, and settling disputes of any kind between the master, the officers and the seamen in so far as this may be authorized by the laws and regulations of the sending State;

(m) performing any other functions entrusted to a consular post by the sending State which are not prohibited by the laws and regulations of the receiving State or to which no objection is taken by the receiving State or which are referred to in the international agreements in force between the sending State and the receiving State.

23. See Report of the ILC, supra note 9 , at $8-9$, art. 5, comments $1-6$, reprinted in [1961] 2 Y.B. Int'l L. Comm'n, supra note 9, at 96.

24. See infra notes $64-73$ and accompanying text.

25. L. Lee, supra note 20 , at 51 .

26. See Heaney v. Spain, 445 F.2d 501 (2d Cir. 1971).

27. See Commonwealth v. Jerez, 390 Mass. 456, 457 N.E.2d 1105 (1983). 
functions, ${ }^{28}$ to operate as a broad license to engage in activities under the protection of immunity. In Heaney $v$. Spain, ${ }^{29}$ the Second Circuit held that contracting with United States citizens to disseminate adverse publicity about a foreign government was compatible with the exercise of consular functions, finding "nothing which would suggest that these alleged activities would not be embraced by the catch-all definition." 90 Therefore, the consular officer was immune from suit for breach of contract.

- Another court expanded the scope of immunity by implicitly interpreting the phrase "in the exercise of consular functions" in article 43 to mean during such exercise, focusing scrutiny solely on the temporal connection between the act and the function. If a function is recognized under article 5, immunity attaches to any act committed during that function's exercise. In Commonwealth $v$. Jerez, ${ }^{31}$ the Supreme Judicial Court of Massachusetts appeared to follow this analysis in holding that a consular officer was immune from suit for assault and battery committed on a police officer as he proceeded to a cultural gathering. ${ }^{32}$

Furthermore, Jerez read narrowly language in the Vienna Convention that might have distinguished the conduct in question from consular functions recognized by article 5 . The court found that the duty to respect the laws of the receiving state under article 55 " "cannot be construed to mean that the doing of a single illegal act takes the activity outside the scope of the consular functions except where specifically so provided in article 5." "33 Therefore, the court reasoned that the consular officer's alleged "single illegal act" of assaulting a policeman did not take his activity outside the scope of consular functions. ${ }^{\mathbf{3 4}}$

2. Narrow Interpretations. - One California appellate court held that "the manner in which ... an authorized function was carried out determine[d] whether [it] was in fact rendered within the scope of consular duties." 35 Literally applied, this standard bases the legitimacy of a consular function on the means chosen to perform it. Where the means are suspect, the ultimate activity is rendered outside the scope of consular functions and immunity is lost.

A restrictive interpretation also has been reached by focusing on

28. See supra note 22 .

29. 445 F.2d 501 (2d Cir. 1971).

30. Id. at 505 .

31. 390 Mass. 456,457 N.E.2d 1105 (1983).

32. Id. at $458-59,457$ N.E.2d at $1106-07$.

33. Id. at 461,457 N.E.2d at 1108 (quoting Illinois Commerce Comm'n v. Salamie, 54 Ill. App. 3d 465, 474, 369 N.E.2d 235, 241 (1977)). The Salamie court reached this conclusion because article 55 provides that the duty to respect the laws of the receiving state is " "without prejudice to [consular officers'] privileges and immunities.' " Salamie, 54 Ill. App. 3d at 474, 369 N.E.2d at 241 (quoting Vienna Convention, supra note 2, art. 55$, ๆ 1$)$.

34. Jerez, 390 Mass. at 461,457 N.E.2d at 1108 .

35. Silva v. Superior Court, 52 Cal. App. 3d 269, 280, 125 Cal. Rptr. 78, 87 (1975). 
the international law principle of noninterference expressed in article 55 of the Vienna Convention. ${ }^{36}$ In Gerritsen $v$. de la Madrid Hurtado, ${ }^{37}$ the Ninth Circuit held that the action of a consular officer who forcibly silenced a demonstrator outside his consulate constituted an "interference with the United States' internal affairs" and thus was not "within the limits permitted by international law."38 Therefore, his action could not properly be protected by the Convention as a consular function. ${ }^{39}$ Under such an approach, presumably any consular activity that adversely affects the interests of the receiving state or its nationals is suspect as an interference in the receiving state's internal affairs.

3. Alternatives. - Commentators have attempted bright-line answers to consular immunity questions, such as distinguishing official from nonofficial acts on the ground that the former are "performed under the authority and on behalf of a State by one of its organs ... so that the act can be imputed to it and deemed an 'act of State." "40 One writer has suggested expanding the length and detail of the list of consular functions in the Vienna Convention so that the immunity attaching to the exercise of these functions would be more clearly defined."1 Another has proposed that courts apply a "substantial departure" test, whereby a substantial departure from an act a consular officer is required to perform indicates that he is acting outside his official duties and therefore not entitled to immunity. 42 Finally, both courts ${ }^{43}$ and commentators ${ }^{44}$ have suggested a political solution to the problem, which would remove responsibility for immunity determinations from the courts and place it with the State Department.

\section{The Theoretical, Policy, and Structural Framework of IMMUNITY UNDER THE VIENNA CoNvENTION}

The text and preparatory work of the Vienna Convention demonstrate that functional necessity was intended to be the basis of consular

36. See supra note 18 .

37. 819 F.2d 1511 (9th Cir. 1987).

38. Id. at 1516.

39. Id.

40. Y. Dinstein, supra note 9, at 23. Dinstein labels acts performed in the course of an official assignment, but not attributable to the state (such as negligent driving) or acts which he argues are consular but not official (such as representing a national in the administration of an estate) "semi-official." He argues that semi-official acts do not exempt the consular officer from judicial process. Id. at 62 .

41. See Green, European Convention on Consular Functions: A Contribution by the Council of Europe to the Development of International Law, 8 Revue Belge de Droit International 176, 187 (1972) (preferring the European Convention on Consular Functions' highly detailed list of consular functions over the Vienna Convention's list).

42. L. Lee, supra note 20 , at $122-23$.

43. See Heaney v. Spain, 445 F.2d 501, 505 (2d Cir. 1971); Arcaya v. Paez, 145 F. Supp. 464 (S.D.N.Y. 1956), aff'd, 244 F.2d 958 (2d Cir. 1957).

44. See Note, Consular Immunity: In Law and in Fact, 47 Iowa L. Rev. 668, 677, $687-88$ (1962). 
immunity. The scope of immunity based on functional necessity is determined by balancing the interests of the sending and receiving states, an underlying policy of the Vienna Convention with which previous interpretations of the Convention are not in accord.

\section{A. Functional Necessity}

In modern times, functional necessity has gained widespread acceptance as the theoretical basis of both diplomatic and consular immunities. 45 The functional necessity theory rests on the premise that without protection from legal and political interference by the receiving state, agents in international relations would be largely at the mercy of their host governments for the degree to which they could fulfill their duties. The threat of such interference alone could "materially hamper them in the exercise of their functions." 46 Today it is generally agreed that consular immunities exist because "it is essential for the proper discharge of consular duties that a consul should be immune from process in the local courts in respect of them."47

The Vienna Convention explicitly adopts the functional necessity theory of consular immunity in its preamble, which states that "the purpose of ... privileges and immunities is not to benefit individuals but to ensure the efficient performance of functions by consular posts on behalf of their respective States." 48 The preparatory work of the Vienna Convention confirms what appears from the face of the text: the delegates to the Conference intended the immunity to safeguard the consular process from unwarranted interference. The delegate who introduced the preamble containing the above phrase stated that " $[t]$ he paragraph expresse[s] the so-called principle of functional necessity which [is] an essential attribute of consular privileges and immunities." 49 Comments of other delegates confirm the intention to recognize functional necessity as the basis of consular immunity. ${ }^{50}$

Nonetheless, the exact contours of consular immunity based on

45. See Note, Consular Immunity From Service of Process Under the Vienna Convention on Consular Relations, 8 Fordham Int'l L.J. 96, 101 (1984) ("The functional necessity theory has, in fact, generally governed the privileges and immunities enjoyed by consular representatives."); see also L. Henkin, R. Pugh, O. Schacter \& H. Smit, International Law: Cases and Materials 948 (2d ed. 1987) (citing authorities).

46. B. Sen, A Diplomat's Handbook of International Law and Practice 82 (1979).

47. Beckett, supra note 12, at 49. But see Y. Dinstein, supra note 9, at 21-23 (arguing that concern for the proper performance of consular functions cannot explain why the immunity applies only to certain acts, because the limited legal and psychological protection the immunity provides is insufficient to ensure unhampered performance of consular functions).

48. Vienna Convention, supra note 2 , preamble, $\uparrow 5$.

49. 1 Official Records, supra note 21, at 246 (statement of Mr. Rao (India)).

50. See id. at 248 (statement of Mr. Ustor (Hungary)) (supporting fifth paragraph of the preamble because it clearly specifies functional necessity as "the one certain basis" of consular immunity); id. at 247 (statement of Mr. Heppel (United Kingdom)). 
functional necessity, or "functional immunity," are not readily apparent. For example, in the extreme, functional immunity could mean complete immunity, since only complete immunity could absolutely ensure that a consular officer's functions would be unimpeded by the receiving state. ${ }^{51}$ At the other extreme, functional immunity could mean nothing more than protection of consular officers from politically motivated acts by the receiving state designed to limit the scope of consular authority; the consular officer would then remain amenable to suit for the slightest deviation from authorized conduct. In short, without further definition, the concept of functional immunity for consular officers is subject to the same vagaries of interpretation as the consular functions rule that attempts to effectuate it.

\section{B. Balancing Interests}

The text, preparatory work, and overall structure of key provisions of the Vienna Convention show that the drafters and conferees intended to balance sending- and receiving-state interests. This balancing provides a means to determine the scope of functional consular immunity.

1. Policy. - Consular immunity is part of customary international law. ${ }^{52}$ Early twentieth century commentary indicates that the scope of consular immunity has long been viewed as the result of a competition between the interests of sending and receiving states. This commentary explains that consular officers perform duties solely for the benefit of the sending state and its nationals in the territory of the receiving state. ${ }^{53}$ As such, the sending state's interests are furthered by the existence of consular immunities, which allows the successful and unhindered performance of these duties. ${ }^{54}$ On the other hand, because "[c]onsular rights and prerogatives [are] in derogation of the territorial jurisdiction of the receiving State," 55 it is in the receiving state's interest to have these immunities interpreted restrictively. ${ }^{56}$ Nonetheless, " $[t]$ he receiving state acquiesces in slight qualifications of its territorial authority in order that it may be permitted to establish consular offices abroad in its own interests." 57

The Vienna Convention, which codified and progressively developed international law on consular immunities, ${ }^{58}$ reflects a similar ac-

51. See Y. Dinstein, supra note 9 , at 21-23.

52. Report of the ILC, supra note 9, at 29 , art. 43 , comment 2 , reprinted in [1961] 2 Y.B. Int'l L. Comm'n, supra note 9, at 117.

53. See Harvard Law School, The Legal Position and Functions of Consuls, in Research in International Law 189, 214-15 (1932).

54. See id. (1926).

55. J. Puente, The Foreign Consul: His Juridical Status in the United States 35

56. See id.

57. The Legal Position and Functions of Consuls, supra note 53, at 214.

58. See supra note 7 . 
commodation of these competing interests. Article 5, the list of consular functions, is composed of both general functions, ${ }^{59}$ which identify the essential purposes of a consular officer's duties, such as "protecting in the receiving State the interests of the sending State and of its nationals," 60 and a series of more specific means to these ends, ${ }^{61}$ such as acting as a notary, ${ }^{62}$ or representing sending-state nationals before tribunals and authorities in the receiving state. ${ }^{63}$ These more specific functions implicate receiving-state interests and are therefore generally subject to regulation or prohibition. This dichotomy between a class of general principles and a list of more specific functions implements a balance of interests by allowing the receiving state to regulate the exercise of specific functions, provided it does not thereby undermine the essential functions at the heart of the consular process.

The preparatory work of the Convention provides additional evidence that the drafters and conferees considered competing interests in drafting article 5. At the Vienna Conference, a debate developed over whether to adopt a general or enumerative definition of consular functions. The article 5 issue, which the ILC had resolved in its draft articles in favor of a nonexhaustive enumeration set out by way of example, ${ }^{64}$ was thrown open by a proposed amendment calling for a general definition. ${ }^{65}$ The conferees invited Jaroslav Zourek, Special Rapporteur of the ILC, ${ }^{66}$ to explain why the ILC had adopted the enumerative text. He responded that consular functions could not be defined solely in general terms because the legal basis for their exercise is not uniform. ${ }^{67}$ In particular, he stated:

Certain consular functions [are] based on customary international law and [have] been established for centuries. Others, however, [have] emerged in more recent times. It was clear to the International Law Commission that the exercise of those consular functions which [are] based on customary interna-

59. Vienna Convention, supra note 2 , art. 5(a)-(c).

60. Id. art 5(a). ILC commentary identifies this as "the most important of the many consular functions." Report of the ILC, supra note 9, at 9, art. 5, comment 7, reprinted in [196I] 2 Y.B. Int'l L. Comm'n, supra note 9, at 96.

61. Vienna Convention, supra note 2 , art. $5(d)-(l)$.

62. Id. art. $5(f)$.

63. Id. art. 5(i).

64. Report of the ILC, supra note 9, at 8-9, art. 5, comment 6, reprinted in [1961] 2 Y.B. Int'1 L. Comm'n, supra note 9, at 96.

65. See generally 1 Official Records, supra note 21, at 124-34 (record of debate).

66. Zourek was appointed Special Rapporteur in 1955, when the ILC began the study of consular intercourse and immunities. He submitted three reports to the ILC, including 60 draft articles, U.N. Docs. A/CN.4/108 (1957), A/CN.4/131 (1960), A/CN.4/137 (1961), which served as the basis for the ILC's discussion and led to its Draft Articles on Consular Intercourse and Immunities. See Report of the ILC, supra note 9, at 2-3, reprinted in [1961] 2 Y.B. Int'l L. Comm'n, supra note 9, at 89-90. The ILC's Draft Articles were in turn used as the working draft at the Vienna Conference.

67. 1 Official Records, supra note 21, at 134-35 (statement of Mr. Zourek (Special Rapporteur)). 
tional law could under no circumstances be prevented by the receiving State. With respect to other functions, however, the position was that a consul could exercise them if they were entrusted to him by the sending State and if their exercise was not forbidden by the authorities of the receiving State. ${ }^{68}$

Subsequent to Zourek's comments, the conferees added saving clauses to four subparagraphs, ${ }^{69}$ expressly subjecting the exercise of each function listed therein to the laws of the receiving state. This action explicitly assigned these functions to Zourek's second category, those whose exercise depends upon acquiescence by both the sending and receiving states.

Also noteworthy is an amendment proposed by Austria that would have left largely unchanged the substantive list of consular functions in article 5, but would have separated the article into two paragraphs: main functions and implementing functions. ${ }^{70}$ Interestingly, this conceptual division corresponds to the dichotomy between general functions, subparagraphs (a) through (c), and specific functions, subparagraphs (d) through $(l)$, apparent from the text. It also received substantial support at the Conference, ${ }^{71}$ including a comment by one delegate that it "reflected the original intention of the International Law Commission."72 While the amendment was never voted on and thus not incorporated into the final draft, the episode suggests that the conferees believed that article 5 as amended by the addition of saving clauses ${ }^{73}$ already reflected the division of functions, and thus the com-

68. Id. at I34. Zourek listed the following as examples of functions that could not be prevented by the receiving state: protecting the interests of the sending state and its nationals; promoting the development of friendly relations between the two states; ascertaining conditions in the receiving state; issuing passports; assisting nationals; and safeguarding their rights in estates. An example of a function that could only be exercised if it did not conflict with receiving-state laws is solemnizing marriages. Id. at 135.

69. The subparagraphs are ( $\mathrm{f}),(\mathrm{g}),(\mathrm{h})$ and $(\mathrm{i})$. Id. at $150-59$. The clause "subject to the practices and procedures obtaining in the receiving State" was added to subparagraph (i), which already contained a saving clause as drafted by the ILC. Id. at 156-59. In addition, a catch-all subparagraph, $(\mathrm{m})$, which also contained a saving clause, was added. Id. at 164-66.

70. 2 id. at 56-57, U.N. Doc. A/CONF.25/C.1/L.26 (1963). The amendment would also have listed two additional implementing functions. See id. For a record of the Vienna Conference's consideration of the amendment, see 1 id. at 147-48, 166-67.

71. See, e.g., id. at 147 (statement of Mr. von Haeften (Federal Republic of Germany)) (supporting the amendment because it "would help future readers to understand the arrangement not only of article 5, but of the convention as a whole"); id. at 148 (statements of Messrs. Wu (China), Palierakis (Greece), Marambio (Chile), Westrup (Sweden) and other supporters). But see id. (statement of Mr. Martins (Portugal)).

72. 1d. at I48 (statement of Mr. Wu (China)).

73. The importance of the amendment was particularly lessened by the adoption of the catch-all definition of consular functions in article $5(\mathrm{~m})$. The delegate who proposed the amendment stated that "as a result of the joint amendment just adopted [adding subparagraph $(\mathrm{m})]$, the Austrian amendment ... modifying the structure of the article had perhaps to some extent lost its points." Id. at I66 (statement of Mr. Kirchschlaeger (Austria)). 
peting interests, of which Zourek spoke.

In addition to the composition of article 5 , the Vienna Convention's treatment of the essential function of protecting the interests of the sending state and of its nationals, at once both regulated and protected by the proviso that the function must be exercised "within the limits permitted by international law,"74 is itself illustrative of the balancing of competing interests. The qualification serves as a check on sending-state power, ${ }^{75}$ while reinforcing the existence of essential functions as general principles of international law. ${ }^{76}$

2. Structure. - The balance struck in article 5 between sendingand receiving-state interests is evident in the overall structure of the Vienna Convention as well. The interplay between articles of the Convention carefully counters a consular officer's duties toward the receiving state with immunities from its jurisdiction.

Article 55 sets out "the fundamental rule"77 that it is each consular officer's duty "to respect the laws and regulations of the receiving State."78 This rule, which appears in the Diplomatic Convention as well, ${ }^{79}$ is particularly significant in regard to consular relations since it provides "a sufficient safeguard for the receiving State" because "consuls, unlike diplomatic agents, [are] subject to the jurisdiction of the receiving State. If, therefore, they violate[] its laws and regulations, the receiving State [is] in a position to enforce observance." 80 At the same time, however, the sending state's competing interest in being free from the enforcement of laws that interfere with the consular process is satisfied by the immunity rule of article 43 , which shields consular officers from receiving-state jurisdiction for acts performed in the exercise of consular functions.

Thus, through the interplay of these two articles, the laws and regulations of the receiving state, which a consular officer must respect,

74. Vienna Convention, supra note 2 , art. 5(a).

75. The proviso "within the limits permitted by international law" was borrowed from the Diplomatic Convention, supra note 16, art. 3, \ 1(b). See Summary Records of the Thirteenth Session, [1961] I Y.B. Int'l L. Comm'n 20, U.N. Doc. A/CN.4/SER.A/1961. Delegates to the Diplomatic Conference supported adding the clause in order to curb abuses by explicitly stating that there are limits to the right of protection. See United Nations Conference on Diplomatic Intercourse and Immunitics, 1 Official Records 79-82, U.N. Doc. A/CONF.20/14, U.N. Sales No. $61 . X .2$ (1961).

76. The proviso can be read as a safeguard against restrictive receiving-state legislation, not itself in conformity with international law, that prevents a consular officer from justly intervening on behalf of the sending state. It was so read by at least one member of the ILC. See Summary Records of the Thirteenth Session, [1961] 1 Y.B. Int'l L. Comm'n, supra note 75, at 19 (statement of Mr. Ago (Italy)).

77. Report of the ILC, supra note 9, at 35, art. 55, comment 1, reprinted in [1961] 2 Y.B. Int'l L. Comm'n, supra note 9, at 123.

78. Vienna Convention, supra note 2 , art. 55 , I 1 .

79. See supra note 18 and accompanying text.

80. I Official Records, supra note 21, at 135 (statement of Mr. Zourek (Special Rapporteur)). 
govern all aspects of the officer's conduct in the receiving state, except insofar as immunity exempts him from their enforcement. In contrast, the "laws and regulations" referred to in the saving clauses of article 5 govern only the exercise of specific consular functions.

Therefore, in civil and criminal actions not involving the violation of a law that regulates the exercise of a consular function, for example, a libel suit or criminal prosecution for assault, it is not sufficient to find immunity from the mere fact that no provision in article 5 removes the act from consular functions; 81 the duty under article 55 remains, enforceable unless immunity is provided by article 43 .

In criminal cases, article 41 supplements the system of checks and balances established in the Convention. This article provides that "[c]onsular officers shall not be liable to arrest or detention pending trial, except in the case of a grave crime." 82 As the ILC noted, "[t]he arrest of a consular official hampers considerably the functioning of the consulate and the discharge of [its] daily tasks" and thereby "harm[s] the interests" of both the sending and receiving states and "seriously affect[s] consular relations between the two States." 83 Therefore, the personal inviolability granted under article 41 provides a siguificant counterbalance to any potential dangers deriving from the enforceable duty to respect the laws of the receiving state.

\section{Prior Standards}

None of the standards of interpretation heretofore applied by the courts is sufficiently attentive to the Convention's underlying premise that sending- and receiving-state interests must be balanced. Unduly broad $^{84}$ and narrow ${ }^{85}$ interpretations threaten receiving- and sendingstate interests, respectively, and fail to recognize the functional basis of consular immunity.

The broad strain of interpretation represented by Commonwealth $v$.

81. See supra notes 33-34 and accompanying text.

82. Vienna Convention, supra note 2 , art. $41, \pi 1$.

In the United States, courts can be expected to interpret "grave crime" to mean a felony. Letter of Submittal from the Department of State to the President, S. Exec. Doc. E, 91 st Cong., 1st Sess. vi (1969). It should be noted that this provision does not mean that consular officers can be prosecuted only for grave crimes, but rather that in the case of a lesser offense, they cannot be imprisoned until convicted. See id,; see also Report of the ILC, supra note 9 , at 28, art. 41, comment 13, reprinted in [1961] 2 Y.B. Int'l L. Comm'n, supra note 9 , at 116 . ("Paragraph 1 of this article refers to immunity from arrest and detention pending trial.... It should be pointed out that this paragraph by no means excludes the institution of criminal proceedings against a consular official.") (emphasis added).

83. Report of the ILC, supra note 9 , at 28 , art. 41 , comment 13, reprinted in [1961] 2 Y.B. Int'l L. Comm'n, supra note 9, at 116.

84. See supra notes $26-34$ and accompanying text.

85. See supra notes $35-39$ and accompanying text. 
Jerez ${ }^{86}$ is inappropriate in two respects. First, granting immunity for all acts performed during the exercise of consular functions was not contemplated by the drafters of the Convention. ${ }^{87}$ Therefore, the fact that Jerez was on his way to a cultural affair at the time of the incident does not, without more, conclusively establish that he was entitled to immunity.

Second, the Jerez court misunderstood the interplay between articles 5 and 55 . Because Jerez was en route to a cultural gathering, the court reasonably concluded that the object of his behavior was the legitimate consular function of "furthering the development of . . . cultural . . relations" 88 between the sending and receiving states pursuant to article $5(\mathrm{~b}) .^{89}$ Yet because article $5(\mathrm{~b})$ contains no clause subjecting the exercise of that function to the laws of the receiving state, the court searched in vain for a "specific provision of article 5 ... which takes Jerez's alleged assault and battery outside the scope of his consular functions." 90 Finding none, the court concluded that Jerez was immune. But the absence of saving clauses in particular provisions of article 5 means that the receiving state cannot prevent the exercise of essential functions through excessively restrictive regulation, not that the duty to respect the laws of the receiving state does not apply. ${ }^{91}$ Therefore, since assault and battery is incompatible with the exercise of consular functions, Jerez is actually not immune under the Vienna Convention's immunity rule, and the laws of the receiving state can be enforced against him.

The difficulty with the result in Jerez is further demonstrated by the inconsistent results its rationale would bring about. If, for example, Jerez had been on his way to perform an administrative function, under the court's reasoning he would not enjoy immunity for the alleged assault and battery because article 5 (f), governing administrative func-

86. 390 Mass. 456, 457 N.E.2d 1105 (1983); see supra notes $31-34$ and accompanying text.

87. This is evident from comments made in regard to the adoption of paragraph 2(b) of article 43 , which provides that the consular functions immunity rule "shall not, however, apply in respect of a civil action ... by a third party for damage arising from an accident in the receiving State caused by a vehicle, vessel or aircraft." Vienna Convention, supra note 2 , art. $43, \uparrow 2$. It might be argued that creating this exception to immunity for an act that often would occur during the performance of consular functions proves the rule that immunity generally attaches to such acts. However, remarks made during debate over the inclusion of this paragraph dispel that notion. The sponsor of this provision "agreed that the act of driving a motor-car should not be regarded as constituting the performance of a consular function for the purpose of claiming immunity from jurisdiction, but [the] amendment was necessary to put the matter beyond doubt." 1 Official Records, supra note 21, at 375 (statement of Mr. Evans (United Kingdom)).

88. Vienna Convention, supra note 2, art. 5(b).

89. 390 Mass. at $458-59,457$ N.E.2d at $1106-07$.

90. Id. at 461,457 N.E.2d at 1108 .

91. See supra notes $68-69,77-81$, and accompanying text. 
tions, contains a saving clause. Nothing in the text or preparatory work of the Convention suggests that such a distinction should be meaningful in immunity determinations.

An expansive view of conduct recognized as consular functions under the catch-all definition in article $5(\mathrm{~m})$, such as the Heaney $v$. Spain 92 court took, may disrupt the balance of interests attained throughout the article and the Vienna Convention as a whole. The Heaney court's interpretation of article $5(\mathrm{~m})$ to include contracting to disseminate adverse publicity about a foreign government, ${ }^{93}$ an activity readily distinguishable from the specific consular functions expressly listed, protects conduct arguably well removed from the consular process, thereby slighting both the explicit recognition of receiving-state interests in that article and the functional necessity principle on which immunity under the Convention is based.

On the other hand, narrow interpretations place inadequate emphasis on the interests of the sending state. The scope of a consular officer's functional immunity cannot be so narrow as to shield him only if he performs his duties faultlessly. If the language of Silva v. Superior Court $^{94}$ implies that to exercise a function improperly is to exceed its bounds, it threatens the doctrine of immunity, ${ }^{95}$ rendering the protection provided illusory.

Similarly, the approach taken by the Gerritsen v. de la Madrid Hurtado $^{96}$ court, which based its immunity determination on a novel reading of the principle that consular officers have a duty not to interfere in the internal affairs of the receiving state, ${ }^{97}$ threatens the consular process and sending-state interests therein. Although the result in Gerritsen is readily defensible-surely consular officers do not need immunity for forcibly silencing protestors outside their missions in order to protect the interests of the sending state-Gerritsen's equation of striking a protestor and confiscating his leaflets with "interference with the United States' internal affairs" 98 unduly extends the boundaries of the noninterference principle. ${ }^{99}$ If interference in internal affairs is read broadly, such legitimate consular activities as gathering and

92. 445 F.2d 501 (2d Cir. 1971); see supra notes 28-30 and accompanying text.

93. See id.

94. 52 Cal. App. 3d 269, 125 Cal. Rptr. 78 (1975); see supra note 35 and accompanying text.

95. Waltier v. Thomson, 189 F. Supp. 319, 321 n.6 (S.D.N.Y. 1960).

96. 819 F.2d 1511 (9th Cir. 1987); see supra notes 37-39 and accompanying text.

97. See id. at 1516 .

98. Id.

99. Exploration of the principle of noninterference in international law is beyond the scope of this Note. However, it has been argued that this principle condemns statelevel interference with the political processes or governmental functions of a foreign state, such as involvement in elections or illicit attempts to influence the policymaking process. See B. Sen, supra note 46 , at $75-77$. 
reporting information on conditions in the receiving state, ${ }^{100}$ for example, might be considered interference. Thus, the Gerritsen rationale might be used as a pretext for improperly restricting the scope of consular functions.

Other proposed solutions to clarifying the scope of immunity, such as distinguishing official from nonofficial acts, ${ }^{101}$ redrafting article $5,{ }^{102}$ or applying a "substantial departure" test, ${ }^{103}$ though not intrinsically prejudicial toward either sending- or receiving-state interests, fail to provide courts with workable standards of interpretation. These proposals either fail to define the boundaries of acceptable consular conduct to which immunity should attach, ${ }^{104}$ or iguore the functional basis of consular immunity. 105

Finally, resolving immunity issues on a political level rather than in the courts is untenable. The Vienna Convention's codification of international law in a binding legal instrument presumes that impartial tribunals ${ }^{106}$ will interpret consular immunity consistently, unaffected by changing political winds and without regard to the current state of bilateral relations between the states involved. Political case-by-case resolution was rejected by the ILC as a usurpation of the judicial function

100. See Vienna Convention, supra note 2, art. 5(c).

101. See supra note 40 and accompanying text.

102. See supra note 41 and accompanying text.

103. See supra note 42 and accompanying text.

104. As the ILC itself recognized, it will be "very difficult" to distinguish official from nonofficial acts. Report of the ILC, supra note 9 , at 29 , art. 43 , comment 3, reprinted in [1961] 2 Y.B. Int'l L. Comm'n, supra note 9, at 117. A test based on this distinction also suffers from circularity: it simply restates the immunity rule of article 43 .

Expanding the length and detail of consular functions in article 5 may eliminate uncertainty in some situations, but as the cases illustrate, the difficulty with the immunity rule often lies not in determining whether a legitimate consular function is involved, but whether a suspect act is "performed in the exercise" of that function. See, e.g., Commonwealth v. Jerez, 390 Mass. 456, 457 N.E.2d 1105 (1983); Waltier v. Thomson, 189 F. Supp. 319 (S.D.N.Y. 1960).

The "substantial departure" test has been criticized as being "rather vague and very general, inspiring little certainty as to how a court would apply it to a specific set of facts." Note, supra note 44 , at 678 . Since each court is likely to have a different view of what constitutes "substantial," this test would provide little consistency in determining the scope of immunity. A court applying this test would still have to balance the interests of the sending and receiving states in order to arrive at a principled interpretation.

105. A proponent of the official/nonofficial act test bases its legitimacy on assertions made prior to the Vienna Convention that consular acts deserve immunity because they are the official acts of a sovereign state. Y. Dinstein, supra note 9 , at 23-24. This contention overlooks the subsequent developments at the Vienna Conference, at which the conferees unanimously adopted a preamble to the Convention that its sponsors had unambiguously stated expressed the functional necessity theory of immunity. See supra notes 48-50 and accompanying text. This departure from pre-Convention theory illustrates the progressive development, in addition to the codification, of customary international law in the Vienna Convention.

106. See supra note 21 and accompanying text. 
in the receiving state. ${ }^{107}$ Moreover, the State Department has shown little interest in encroaching on this function. ${ }^{108}$

\section{Applying a Functional Approach}

\section{A. The Functional Approach Defined}

A functional approach to immunity questions requires examining whether immunity for the act giving rise to suit is necessary for the satisfactory and expedient performance of a recognized consular function. ${ }^{109}$ Article 5 is the source for determining whether a recognized consular function is involved. In answering whether immunity for the specific act in question is necessary for the performance of that function, it must be remembered that consular immunity is not intended to benefit the individual. ${ }^{110}$ Thus, the essence of the inquiry is not whether the defendant consular officer deserves immunity solely because he would have been unable, without the act, to perform the function, ${ }^{111}$

107. The Provisional Draft Articles on Consular Intercourse and Immunities, prepared by Zourek, contained a second paragraph in what is now article 43 that provided: "Where a member of the consular staff invokes the above immunity ... all difficulties of this kind must be settled solely through the diplomatic channel." U.N. Doc. A/CN.4/L.86 at 13 (1960), reprinted in [1960] 2 Y.B. Int'l L. Comm'n 37, U.N. Doc. A/CN.4/SER.A/1960/Add.1. In the debate among ILC members over this provision, it was argued that " $[t]$ he interpretation of consular immunities and privileges should be left to the courts of the receiving State." Summary Records of the Twelfth Session, [1960] 1 Y.B. Int'l L. Comm'n 79, U.N. Doc. A/CN.4/SER.A/1960 (statement of Mr. Erim (Turkey)); see also id. at 78 (statement of Sir Fitzmaurice (United Kingdom)) ("It [is] difficult to see how a country ... could accept the proposition that the mere fact of immunity being invoked would prevent a court from pronouncing ...."). The provision was rejected eleven votes to two, with three abstentions. Id. at 79.

108. See 1978 Digest of United States Practice in International Law § 2, at 629-30.

[T] he Department [of State] regards itself as being in a position to give advice to sending states concerning whether a particular activity qualifies as a recognized consular function....

Nevertheless, it is the Department's view that ... it is only the trier of facts which is in a position to make the determination as to the "official" nature of the activity.

Id. at 630.

109. The reasoning in two pre-Convention cases illustrates the type of functional approach advocated here. In Waltier v. Thomson, 189 F. Supp. 319 (S.D.N.Y. 1960), the court recognized that since it was the consular officer's duty to interview and advise prospective immigrants, he enjoyed immunity from suit for an alleged misrepresentation made in such an interview. Id. at 321. Implicit is the recognition that the opposite rule could chill a consular officer's willingness to give advice.

In a French case, Judgment of Jan. 28, 1928, Cass. crim., Fr., 1928 Gazette du Palais [G.P.] 726, translated and reprinted as Bigelow v. Princess Zizianoff in 23 Am. J. Int'l L. 172 (1929), the court held a consular officer amenable to a libel suit arising out of his allegedly false reports to the press as to why a visa had been refused, because the report was not the "necessary and indispensible corollary" of the consular function of granting visas. 1d. at 179 .

110. See supra note 48 and accompanying text.

111. The Jerez court appears to have followed this mistaken line of inquiry. It stated 
but whether the consular process would be impeded if consular officers were amenable to the jurisdiction of the receiving state for such acts. ${ }^{112}$

The functional approach effectuates the policy concerns evident in the preparatory work and structure of the Convention by requiring an inquiry into the significance of the act complained of to the relative interests of the sending and receiving states. It also obviates any need to draw on external sources of law, a common approach among courts facing immunity questions. ${ }^{13}$ This approach increases the likelihood that different courts will reach different results in similar cases and that decisions will rest on principles not well suited to the consular context.

\section{B. The Functional Approach Applied}

Application of the functional approach to administrative, civil, and criminal actions demonstrates its utility as a basic method of answering immunity questions. Such an approach resolves most of the interpretive problems that arise and provides a framework for answering those questions it cannot definitively resolve.

1. Immunity from Administrative Action. - Consider an administrative action brought against a consular officer for violation of a law prohibiting consular officers from obtaining provisional representation for sending-state nationals before tribunals in the receiving state. Application of the functional approach in this case will result in immunity. This is so because the law overreaches permissible regulation of a recognized consular function and threatens the exercise of an essential consular function: protecting the interests of sending-state nationals. ${ }^{114}$

The result would be different, however, if the consular officer had violated a law requiring that representation before the receiving state's tribunals be performed by a lawyer. He would be amenable to suit because the law implements a receiving state's legitimate interest in controlling the qualifications of those who practice before its tribunals. ${ }^{115}$ Moreover, because alteruative means of obtaining representation remain available to the consular officer, the regulation does not

that since "Jerez's alleged wrongful conduct occurred in response to conduct which was presently interfering with his ability to exercise his consular functions successfully ...., [he] was acting within the scope of his authority when the altercation occurred." Commonwealth v. Jerez, 390 Mass. 456, 463, 457 N.E.2d 1105, 1109 (1983).

112. See supra notes $48-49$ and accompanying text. Commentators have properly focused on the process rather than the individual with regard to diplomatic immunity. See Note, Diplomatic Immunity: A Proposal for Amending the Vienna Convention to Deter Violent Criminal Acts, 5 B.U. Int'l L.J. 177, 210 \& n.132 (1987).

113. See, e.g., Lyders v. Lund, 32 F.2d 308, 309 (N.D. Cal. 1929) (drawing analogy between consular immunity and immunity of state officials under the eleventh amendment); Commonwealth v. Jerez, 390 Mass. 456, 461-62, 457 N.E.2d 1105, 1108 (1983) (supporting decision by reference to common-law agency principles).

114. See supra notes $59-60$ and accompanying text.

115. See supra note 63 and accompanying text. 
unreasonably, and therefore impermissibly, interfere with an essential function; consular officers can comply with the regulation and still safeguard the interests of sending-state nationals.

2. Immunity from Civil Suit. - Consider two civil suits arising from a consular officer's denial of a visa to a prospective traveler to the sending state: the first is based on the denial itself, the second on the consular officer's allegedly defamatory reports to the press concerning the reasons for the denial. ${ }^{116}$ Under article 5 of the Vienna Convention, issuing visas to persons wishing to travel to the sending state is a recognized consular function. ${ }^{117}$ Application of the functional approach will result in immunity from the first suit, ${ }^{118}$ because immunity for denial of a visa is essential if consular officers are to carry out that function free of the intimidation and interference that exposure to such suits would create. These effects could materially impair the sending state's ability to monitor the influx of foreigu travelers, a primary interest served by this consular function. On the other hand, since the consular process would suffer no deleterious effects if its officers were exposed to suit for making defamatory reports to the press about visa denials, the functional approach does not insulate the consular officer from the second suit. ${ }^{119}$ In the latter case, the interests of the receiving state in protecting the reputations of its citizens outweigh the minimal interests of the sending state in safeguarding the consular process from such interference.

Immunity from civil suits based on contracts concluded by consular officers involves a separate provision of article 43 , which states that the consular functions immunity rule shall not apply "in respect of a civil action ... arising out of a contract concluded by a consular officer ... . in which he did not contract expressly or impliedly as an agent

116. The facts of the second hypothetical are drawn from Judgment of Jan. 28, 1928, Cass. crim., Fr., 1928 G.P. 726, translated and reprinted as Bigelow v. Princess Zizianoff, in 23 Am. J. Int'l L. 172 (1929).

117. Vienna Convention, supra note 2, art. 5(d).

118. The Princess Zizianoff court recognized that the consular officer would have been immune from suit based on the facts of the first hypothetical. See Judgment of Jan. 28, 1928, Cass. crim., Fr., 1928 G.P. at 729, translated and reprinted as Bigelow v. Princess Zizianoff in 23 Am. J. Int'l L. 172, 179 (1929).

119. The conclusion that consular officers do not generally enjoy immunity for tortious conduct is supported by a recent holding in the Ninth Circuit that a consular employee (enjoying immunity equivalent to that of a consular officer under article 43) was not immune from suit for allegedly tortious acts committed in connection with a residence rented by the Consulate for his use, because "no public interest or function of the Consulate or [the sending state] was furthered by the allegedly tortious acts." See Joseph v. Consulate General of Nigeria, 830 F.2d 1018, 1027 (9th Cir. 1987), cert. denied, 56 U.S.L.W. 3590 (U.S. Feb. 29, 1988) (No. 87-1134).

Further support for this conclusion derives from the text of the Vienna Convention, which declares the immunity rule inapplicable in civil actions arising out of traffic accidents. See supra note 87 . Since traffic accidents are an example of private activity exposed to suit, it can be inferred that other tortious conduct falls outside the scope of consular functions as well. 
of the sending State."120 The provision was added by an amendment proposed by the United Kingdom utilizing the wording of its bilateral consular conventions. ${ }^{121}$ This language, which suggests by negative implication that contracting as an agent of the sending state is, without more, sufficient to provide immunity from contract suits, ${ }^{122}$ creates ambiguities by implying a departure from the consular functions immunity rule expressed in the first paragraph of article 43. However, this provision was added solely to ensure the protection of third parties ${ }^{123}$ by specifically excluding from immunity suits based on privately concluded contracts. ${ }^{124}$ As such, it can be viewed as adding nothing to the existing consular functions rule. ${ }^{125}$ Thus, a reasonable interpretation is that, as in pre-Convention cases, ${ }^{126}$ consular officers enjoy immunity from suit for breach of contract solely where they have contracted in the performance of consular functions. ${ }^{127}$

Immunity from claims arising out of contracts concluded in the course of consular duties is required to shield consular officers from the threat of suit and financial liability that could seriously affect their performance. As the activity on which the contract is based moves further toward the periphery of recognized consular functions, ${ }^{128}$ however, the

120. Vienna Convention, supra note 2 , art. 43 , ๆ 2.

121. Nascimento e Silva, supra note 14 , at 1227.

122. See supra note 120 and accompanying text.

123. 1 Official Records, supra note 21, at 374 (statement of Mr. Evans (United Kingdom)).

124. L. Lee, supra note 20 , at 143.

125. See Nascimento e Silva, supra note 14, at 1227 ("One can reasonably say that this provision was only included ex abundanti cautela, since paragraph 1 excludes immunity for private action such as are [sic] expressly mentioned in paragraph 2."); see also $S$. Exec. Doc. E, 91st Cong., Ist Sess. 64 (1969) ("Consular officers are, like any private party, subject to the jurisdiction of the receiving state with respect to their private acts. This is emphasized by subparagraph 2 (a) ....”).

126. Compare Landley v. Republic of Panama, 31 F. Supp. 230 (S.D.N.Y. 1940) (consular officer immune from suit for breach of promise to keep information on services rendered by plaintiff to sending state confidential, because action was based on duties performed as consul general) with Nashashibi v. Consul-Gen. of France (Jordan, Supreme Court of Cassation (1958)) (unpublished report No. 162/958), reprinted in 26 I.L.R. 190 (1958 II) (consular officer amenable to.suit for breach where he explictly contracted as an agent of his government, because conclusion of contract was not a consular act).

127. See Heaney v. Spain, 445 F.2d 501 (2d Cir. 1971) (consular officer contracted as agent of sending state, yet court considered consular functions issue before finding immunity); see also Joseph v. Consulate Gen. of Nigeria, No. C-84-6134 WHO (N.D. Cal. Aug. 12, 1986) (although plaintiff dropped breach of contract claim, opinion indicates that parties considered the consular functions rule to be controlling in immunity determination, with no indication court viewed issue differently), aff'd, 830 F.2d 1018 (9th Cir. 1987), cert. denied, 56 U.S.L.W. 3590 (U.S. Feb. 29, 1988) (No. 87-1134).

128. See Heaney, 445 F.2d at 501 (consular officer concluded contract with United States citizen to disseminate adverse publicity about another foreign government in hope that this would oust other government from area in which contracting government had interests). 
need to protect the consular process by finding immunity is less compelling.

3. Immunity from Criminal Prosecution. - The balancing of sendingand receiving-state interests that drives the functional approach works to limit the scope of immunity in criminal cases such as Jerez. 1llegal acts, particularly those that are malum in se, are incompatible with the exercise of consular functions ${ }^{129}$ and seriously impinge on receivingstate interests. Violence is not essential to the consular process; therefore, its officers do not need the protection of immunity for such acts in order to carry out their functions. If the functional approach narrowly circumscribes the scope of consular immunity from criminal prosecution for violent acts, it is to protect the receiving state against the worst abuses of immunity. ${ }^{130}$

In fact, there may never be cases in which otherwise criminal conduct is immunized by the Vienna Convention. While the enforcement of criminal laws may at times affect the manner in which a consular officer performs his functions, the Vienna Convention protects the consular process, not the individual. ${ }^{131}$ The consular process does not require the execution of criminal acts. Therefore, amenability to jurisdiction for such conduct is fully consistent with the functional necessity theory of immunity. ${ }^{132}$

Nonetheless, there will be difficult cases in which it is unclear whether receiving-state regulation will have a debilitating impact on an essential function, or in which it is difficult to determine whether a recognized consular function is involved and the conflicting interests of the sending and receiving states are evenly matched. However, the functional approach should reduce the potential for inconsistent interpretations by courts faced with immunity questions and increase the degree of certainty in this aspect of consular relations by providing a coherent standard by which consular conduct can be measured.

129. L. Lee, supra note 20 , at 129 ; Note, supra note 44 , at $673-74$.

130. For an argument that the broad scope of diplomatic immunity should be narrowed to exclude violent criminal conduct in order to curb abuses, see Note, supra note 112 , at 203-07.

131. See supra notes 110-12 and accompanying text. Arguably, a pattern of false accusations of even minor crimes could interfere with the consular process. Only complete criminal immunity, however, could foreclose this threat; yet the Vienna Convention does not provide such broad immunity. See supra note 19 and accompanying text. The likelihood of this type of threat to the process is small and can be addressed by the more tailored remedy of providing broader immunity on the bilateral level. See supra note 15.

132. In addition, the preparatory work of the Vienna Convention supports the conclusion that amenability to the jurisdiction of the receiving state for lesser criminal offenses was contemplated by the drafters. See supra note 82 . Moreover, the Vienna Convention provides safeguards against such exposure becoming an unwarranted hindrance to consular functions. See supra notes $82-83$ and accompanying text. 


\section{CONCLUSION}

Prior interpretations of the Vienna Convention have left the scope of consular immunity uncertain. However, the text, preparatory work, and structure of the Vienna Convention show that consular immunity derives from its functional necessity and is delimited in scope by balancing competing sending- and receiving-state interests. A functional approach to immunity questions can resolve most interpretive problems and provide a framework for answering those questions it cannot definitively resolve.

Curtis J. Milhaupt 